\title{
Studies on the Ecological Life History of the Indian-Meal Moth, Plodia interpunctella HÜBNER
}

\author{
I. Comparative Studies of the Three Stocks with Special \\ Reference to the Onset of Diapause ${ }^{1}$
}

\author{
By Hideakira TsuJI \\ Entomological Laboratory, Kyoto University, Kyoto
}

\section{INTRODUCTION}

In preceding papers it was shown that the Indian-meal moth, Plodia interpunctella HÜBNER has a new type of diapause and the onset of diapause is governed both by the condition of temperature and by larval density when the larvae are reared in a short day length (Tsuji, 1958a, 1959a).

If the individuals are reared at $30^{\circ} \mathrm{C}$ during the early stages (from their parental stage up to the egg stage, or up to the 1st, 2nd or 3rd instar stage) and removed to $20^{\circ} \mathrm{C}$, all or nearly all of them enter diapause at the fully grown stage, whereas some or no larvae enter diapause when removed at the later stages (the 4 th or 5th instar stage).

On the other hand, the arrested larvae pupate promptly without any interruptions when they are removed again from $20^{\circ} \mathrm{C}$ to a high $\left(30^{\circ} \mathrm{C}\right)$ temperature condition.

Under the $30^{\circ} \mathrm{C}$ temperature condition no larvae enter diapause so far as they are reared in the condition of low larval density (50 eggs per $30 \mathrm{~g}$ rice bran). A considerable number of individuals, however, wander out of the food at the fully grown stage when they are reared in high larval densities (100 400 eggs per $30 \mathrm{~g}$ rice bran). These wandering fully grown larvae proved to be the individuals which had entered diapause by the high larval densities but actually had no any diapausing period because they were kept under the high temperature.
Further studies on the ecological meanings of the temperature-dependent onset of diapause and of the density-dependent one are being carried out. However, a new problem was recently offered. There has occurred $a^{\prime}$ reduction in the number of density-dependent diapause individuals in the original stock at $30^{\circ} \mathrm{C}$ and it has become highly difficult to get them if this stock was used. In addition, by repeatedly breeding from the original stock, there evolved other stocks in which the modes of response to temperature and larval density were different from those of original stock (TsuJI, 1959b). It is fortunate for further experiments that one of them has a high sensibility to larval density.

The purpose of this paper is to describe the modifications in temperature or density response in these stocks, to give more strict materials for further experiments and to contribute general considerations of the ecological life history.

\section{MATERIAL AND METHODS}

A large number of adults were caught in one of storehouses at Senbon-Nijo in Kyoto in the early summer of 1955 , and were kept in a petri dish with a certain quantity of rice bran into which the females oviposited freely. Their progenies were repeatedly bred at $30^{\circ} \mathrm{C}$ and $45 \sim 75 \%$ $\mathrm{RH}$, and were named $" 30^{\circ} \mathrm{C}$ original stock" or OS in short.

For each generation, several batches of 200 eggs each were used, each batch being

\footnotetext{
${ }^{1}$ Contribution from the Entomological Laboratory, Kyoto University, No. 338.
} (Received for publication, June 18, 1960) 
put into a large petri dish $(11 \mathrm{~cm}$. in diameter; $3.5 \mathrm{~cm}$ in depth, covered up with a glass plate in the centre of which was a round hole of $3 \mathrm{~cm}$ diameter covered with a paper) with $30 \mathrm{~g}$ of rice bran on which the larvae fed. In some generations of this stock the rearing was initiated with a certain number of adults kept in a large petri dish with a certain amount of rice bran, and after a time a large number of the larvae which developed in the dish were divided into several large glass dishes containing an adequate quantity of new rice bran.

The eggs were collected in the following way. When some or most of the adults had emerged they were collected from the petri dishes and were put into a glass cylinder $(11 \mathrm{~cm}$ in diameter, $15 \mathrm{~cm}$ in length) in which the females deposited eggs. The upper end of the glass cylinder was covered up with a glass plate and the bottom was fitted with a wirenetting of 24 meshes through which the eggs fell down. A large petri dish was placed under the cylinder, and the eggs laid were collected together daily or sometimes at intervals of $2 \sim 4$ days, counted and used for the experiments and stocks.

As containers, two sizes of petri dishes were used. Larger dishes were the same as used for making OS, and small ones were $7 \mathrm{~cm}$ in diameter and $3 \mathrm{~cm}$ in depth, and covered up with a glass plate having a hole covered with paper.

The containers were placed on shelves in constant temperature rooms. In one of the rooms the temperature remained constant at $30 \pm 0.5^{\circ} \mathrm{C}$, the relative humidi- ty ranging from $45 \%$ to $75 \%$. In the other room the temperature was $18 \sim 20^{\circ} \mathrm{C}, 19 \sim$ $21^{\circ} \mathrm{C}$ or sometimes $20 \sim 21^{\circ} \mathrm{C}$, but all of them were regarded as about $20^{\circ} \mathrm{C}$, and the relative humidity was $45 \sim 85 \%$. The duration of light was less than 11 hours a day.

The water content of rice bran was 8 $12 \%$ before the experiments were begun and it did not vary so much during the experiments except in the condition of high relative humidity of the air.

\section{EXPERIMENTAL RESULTS}

1. Some modification in the density response in $30^{\circ} \mathrm{C}$ original stock $(O S)$. - Table 1 shows that during three years from 1956 to 1959 there was a reduction in the number of density-dependent diapause individuals in OS. In this stock, under existing circumstances, it is highly difficult to get a large population of such individuals sufficient for experiments.

In addition to this it seems that the reduction in the number of density-dependent diapause individuals had already occurred before the time when the results shown in the table were obtained in 1956, because in 1955 when the stock-making was initiated the wandering of the fully grown larvae, developed from 600 eggs per $40 \mathrm{~g}$ rice bran in each petri dish, was much more remarkable than in 1956, though no record was taken in 1955.

2. $20^{\circ} \mathrm{C}$ non-diapause stock $A(N S-A)$.In the case where the larvae of OS were reared at $20^{\circ} \mathrm{C}$ they entered diapause at a fully grown stage but after a long resting period they pupated and emerged ${ }^{1}$. Several moths produced in such a way

Table 1: A reduction in the number of density-dependent diapause individuals in $O S$ reared at a density of 400 eggs per $30 \mathrm{~g}$ of rice bran at $30^{\circ} \mathrm{C}$

\begin{tabular}{lccccc}
\hline Date & $\begin{array}{c}\text { Number of } \\
\text { dishes }\end{array}$ & Eggs & $\begin{array}{c}\text { Larvae } \\
\text { diapaused }\end{array}$ & $\begin{array}{c}\text { Larvae } \\
\text { diapause-free }\end{array}$ & $\begin{array}{c}\text { Per cent } \\
\text { diapause }\end{array}$ \\
\hline Dec. 1956 & 3 & 1200 & 197 & 633 & 23.7 \\
Dec. 1957 & 4 & 1600 & 160 & 942 & 14.5 \\
Nov. 1959 & 2 & 800 & 3 & 473 & 0.6 \\
\hline
\end{tabular}

1 Recently it became usual in OS that a few. $(4 \sim 6 \%)$ diapause-free individuals were obtained, and they emerged $60 \sim 70$ days after hatching at $20^{\circ} \mathrm{C}$. 
were introduced in some large petri dishes in each of which a couple of male and female mating or not was confined with $40 \mathrm{~g}$ of rice bran into which the female oviposited freely, and the emergence of the next generation was examined.

Then the beginning of emergence of the adults was earlier than that of the parental generation, and a few of the adults emerging foremost seemed to be diapausefree individuals as they emerged $70 \sim 80$ days after the introduction of their parents into the dish. In this case, however, there was no clear segregation between the time of emergence of the diapause-free individuals and that of the diapause individuals, there being rather a continuity between them.

By repeatedly breeding from such moths as emerged foremost, which escaped diapause and produced more diapause-free progenies than others did (the last breeding was carried out by selecting a few dishes in which the earlier pupation was most remarkable among similar dishes of the same generation), a stock was evolved that produced little or no diapause larvae so far as they were reared under a constant temperature of $20^{\circ} \mathrm{C}$, and named here " $20^{\circ} \mathrm{C}$ non-diapause stock A" or NS$A$ in short. The accumulated emergence curves of three dished of $F_{4}$ (in summer of 1959) are shown in Fig. 1, in which the curve of parental generation (in Dec, 1958) is drawn for comparison.

3. $20^{\circ} \mathrm{C}$ non-diapause stock $B$ (NS-B). As previously reported, when the larvae

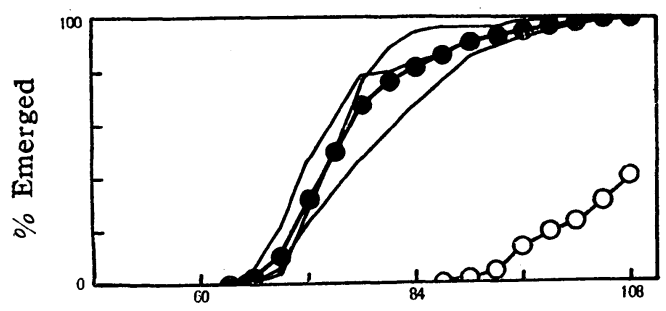

Time in days

Fig. 1. The accumulated emergence curves of three $\mathrm{F}_{4}$ dishes of NS-A and the average values(O), compared with that of parental generation $(O)$

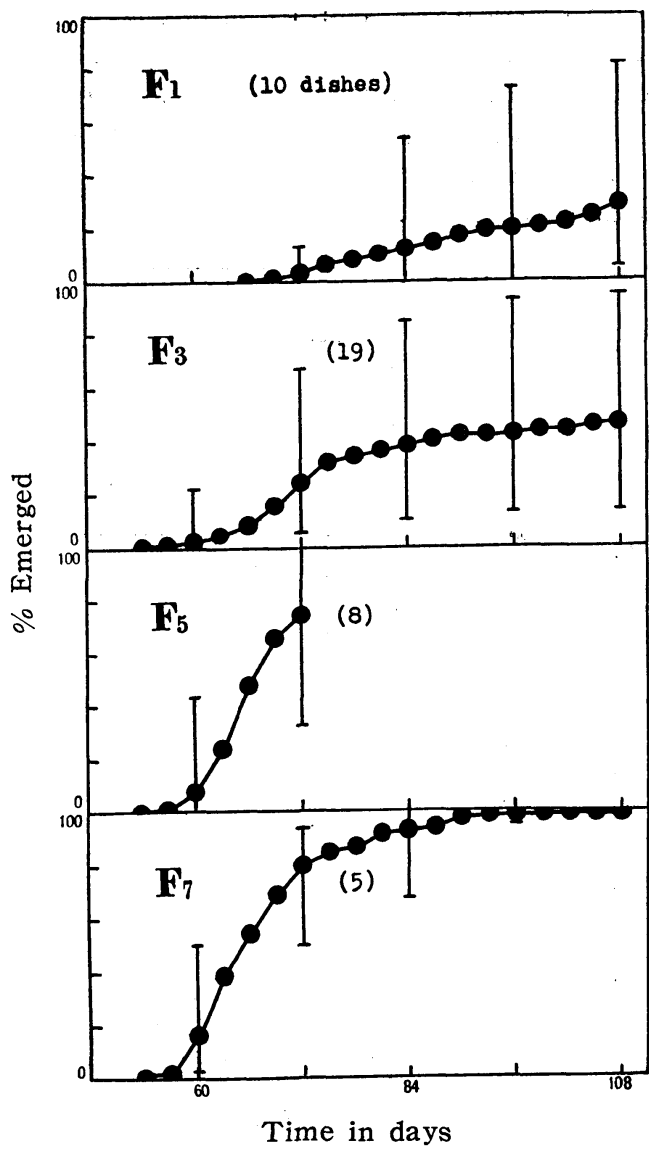

Fig. 2. The processes in which NS-B was evolved, showing the average (O), maximum and minimum values (vertical lines)

of this species were reared at $30^{\circ} \mathrm{C}$ up to 4 th or 5 th instar stage before they. were removed to $20^{\circ} \mathrm{C}$, most of them did not enter diapause at a fully grown stage, and pupated promptly.

From these adults a stock was evolved by the same procedure as in NS-A that pupated also without interruption at $20^{\circ} \mathrm{C}$, and named here " $20^{\circ} \mathrm{C}$ non-diapause stock B" or NS-B in short. The pattern of the modification in the temperature response in this stock was also the same as that of NS-A as shown in Fig. 2.

4. $20^{\circ} \mathrm{C}$ diapause stock $(D S) .-\mathrm{By}$ the same handling method as described in NS and by repeated breedings from the moths which entered diapause, emerged last of 
all, and produced less diapause-free progenies than other moths did, another stock was evolved that produced little or no diapause-free individuals in every generation at about $20^{\circ} \mathrm{C}$. The results up to $\mathrm{F}_{3}$ are shown in Fig. 3.

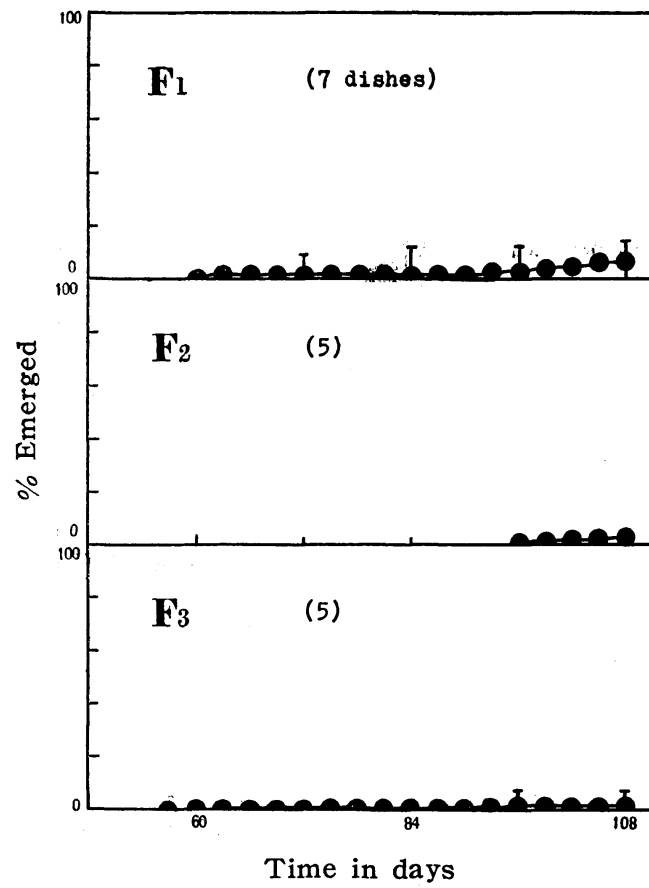

Fig. 3. The processes in which DS was evoled, showing the average(O), maximum and minimum values (vertical lines)

5. The mode of temperature response in each stock. - The mode of temperature response in each stock in which the larvae were reared in the condition of low larval densities is summarized in Table 2 to facilitate comparisons between the three stocks.

OS: As described in the introduction the mode of temperature response in OS has already been reported (TsujI, 1958a). In this stock, however, it has recently become usual that a few diapause free individuals pupated even if they were reared at $20^{\circ} \mathrm{C}$ from the egg stage, though no diapause-free individuals occurred when they were reared at $30^{\circ} \mathrm{C}$ up to the middle instar stage at which they were removed to $20^{\circ} \mathrm{C}$.

NS : The mode of temperature response in NS-B has also been reported (TsujI, 1959b). In NS-A, the effect of initial exposure of larvae to $30^{\circ} \mathrm{C}$ upon the inception of diapause when returned to $20^{\circ} \mathrm{C}$ proved to be similar to that of NS-B, though other aspect has not been clarified.

DS : As previously described little or no diapause-free individuals were produced in each generation so far as they were reared at $20^{\circ} \mathrm{C}$ and this was also true in the case in which they were reared at $30^{\circ} \mathrm{C}$ from the egg stage up to the middle larval instar at which they were removed to $20^{\circ} \mathrm{C}$. This was shown in an experiment in which two batches of 100 eggs each per $30 \mathrm{~g}$ of rice bran and a batch of 400 eggs per $30 \mathrm{~g}$ of rice bran were used, there being no diapause-free individuals.

6. The mode of density response in each stock.

a) Comparisons between the three stocks at $30^{\circ} \mathrm{C}$.

To demonstrate the sensibility to high larval densities in each stock, an experiment was carried out in December, 1959. Some batches of 100 and 400 eggs each were used in each stock. Each batch was kept in a large petri dish with $30 \mathrm{~g}$ of rice bran. The procedures and results

Table 2. Comparisons of the mode of temperature response between the three stocks reared in the condition of low larval densities

\begin{tabular}{ccc|ccc}
\hline \multicolumn{2}{c|}{ Stages and temperatures } & \multicolumn{3}{c}{ Stocks and diapausing larvae } \\
\cline { 1 - 5 } $\begin{array}{c}\text { Parents and } \\
\text { oviposition }\end{array}$ & $\begin{array}{c}\text { Eggs and } \\
\text { young larvae }\end{array}$ & Old larvae & NS & OS & DS \\
\hline $30^{\circ} \mathrm{C}$ or $20^{\circ} \mathrm{C}$ & $30^{\circ} \mathrm{C}$ & $30^{\circ} \mathrm{C}$ & No & No & No \\
& $30^{\circ} \mathrm{C}$ & $20^{\circ} \mathrm{C}$ & All & All & All \\
& $20^{\circ} \mathrm{C}$ & $20^{\circ} \mathrm{C}$ & Little or no Nearly all or all All or nearly all \\
\hline
\end{tabular}


Table 3. Comparisons of the mode of density response between the three stocks reared at $30^{\circ} \mathrm{C}$

\begin{tabular}{|c|c|c|c|c|c|c|}
\hline & \multicolumn{3}{|c|}{100 eggs per $30 \mathrm{~g}$ of rice bran } & \multicolumn{3}{|c|}{400 eggs per $30 \mathrm{~g}$ of rice bran } \\
\hline & NS & OS & DS & NS & os & DS \\
\hline Date of egg collection & $\begin{array}{c}\text { Dec. } 4, \\
1959\end{array}$ & $\begin{array}{c}\text { Nov. } 16 \\
1959\end{array}$ & $\begin{array}{l}\text { Nov. } 18, \\
1959\end{array}$ & $\begin{array}{l}\text { Dec. 4, } \\
\quad 1959\end{array}$ & $\begin{array}{c}\text { Nov. } 16, \\
1959\end{array}$ & $\begin{array}{c}\text { Nov. } 18, \\
1959\end{array}$ \\
\hline $\begin{array}{l}\text { Number of } \\
\text { dishes } \\
\text { eggs used } \\
\text { larvae diapaused } \\
\text { larvae escaped diapause } \\
\text { Per cent }\end{array}$ & $\begin{array}{r}2 \\
200 \\
0 \\
142\end{array}$ & $\begin{array}{r}2 \\
200 \\
0 \\
120\end{array}$ & $\begin{array}{r}1 \\
100 \\
1 \\
83\end{array}$ & $\begin{array}{r}2 \\
800 \\
2 \\
478\end{array}$ & $\begin{array}{r}2 \\
800 \\
3 \\
473\end{array}$ & $\begin{array}{r}2 \\
800 \\
307 \\
277\end{array}$ \\
\hline $\begin{array}{l}\text { mortality } \\
\text { diapause }\end{array}$ & $\begin{array}{r}29 \\
0\end{array}$ & $\begin{array}{r}40 \\
0\end{array}$ & $\begin{array}{l}16 \\
1.2\end{array}$ & $\begin{array}{l}40 \\
0.4\end{array}$ & $\begin{array}{l}40 \\
0.6\end{array}$ & $\begin{array}{l}27 \\
52.4\end{array}$ \\
\hline
\end{tabular}

are shown in Table 3, which are essentially similar to those obtained in the preliminary experiments in each stock. It is evident that DS is highly sensitive to the larval density, but OS and NS are not.

b) An exceptionally high density rearing in $\mathrm{OS}$ at $30^{\circ} \mathrm{C}$.

There has been a reduction in the number of densitydependent diapausing individuals in OS under the condition of larval densities below 400 eggs per $30 \mathrm{~g}$ of rice bran. So, an experiment was carried out in the spring of 1959 to investigate the effect of much higher

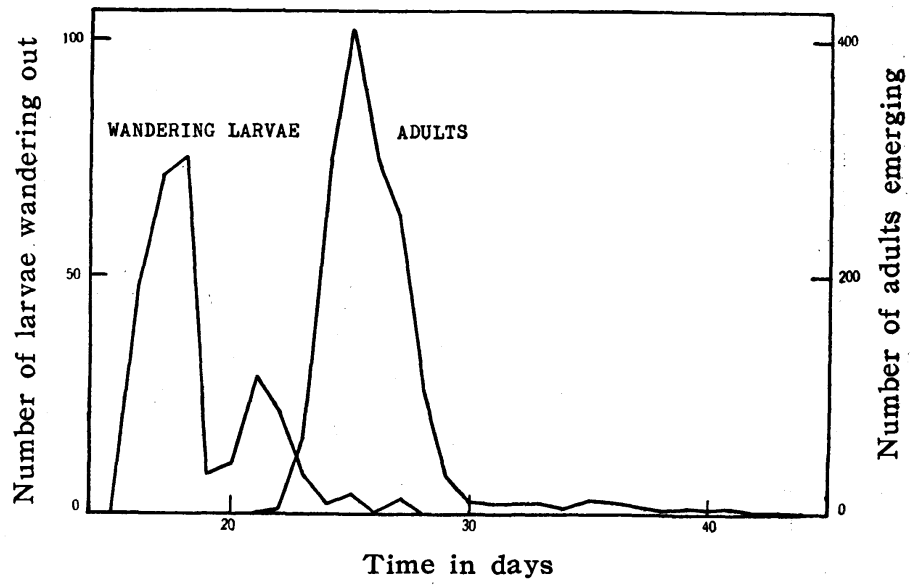

Fig. 4. The occurrence of wandering fully grown larvae in OS reared at a density of 600 eggs per $30 \mathrm{~g}$ of rice bran at $30^{\circ} \mathrm{C}$ (Total of four dishes) density upon OS. Four large petri dishes were used. In each dish 600 eggs were kept with $30 \mathrm{~g}$ of rice bran. The wandering fully grown larvae and the adults emerging were picked out of the dish every day, and the larvae picked out were divided into two populations, each of which was kept in a small petri dish with a certain amount of rice bran and removed to $20^{\circ} \mathrm{C}$ or left at $30^{\circ} \mathrm{C}$ where the emergence of adults was observed. The results obtained are shown in Figs. 4 and 5.

It is clear from Fig. 4 that there are two peaks in the occurrence of wandering fully grown larvae. The time when the first peak occurred was too early to be regarded as that of the occurrence of density-dependent diapause larvae as reported before (Tsuji, 1959a), while there was a reasonable agreement between the time when the second peak occurred and that when the density-dependent diapause larvae wandered out of the food as reported before. The difference between the two peaks was also shown with regard to the time when their emergence occurred at $20^{\circ} \mathrm{C}$ or at $30^{\circ} \mathrm{C}$, though in the larvae of second peak, especially at $20^{\circ} \mathrm{C}$, the emergence occurred earlier than that of the diapaused larvae which had been reported before. So it seems that the occurrence of diapause is not remarkable even in such a high density.

c) The effect of larval density on the 


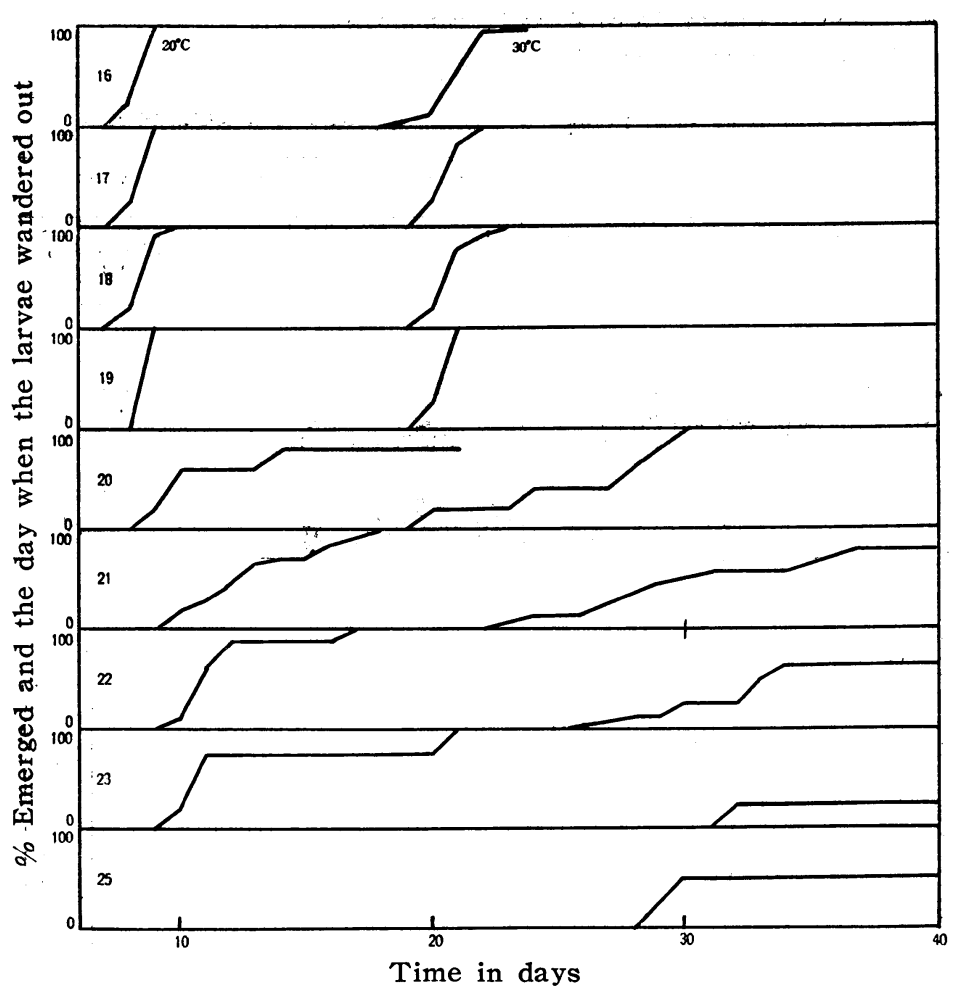

Fig: 5. The accumulated emergence curves of the larvae which were picked out every day and were kep at $30^{\circ} \mathrm{C}$ or $20^{\circ} \mathrm{C}$

at $30^{\circ} \mathrm{C}$. In addition, the larvae wandering out of food were also similar to those of the first peak of the exceptionally high density rearing in OS in regard to pupation without any interruption at $20^{\circ} \mathrm{C}$, so that little or no larvae of NS seem to enter diapause depending upon the high larval density at $20^{\circ} \mathrm{C}$.

\section{DISCUSSION}

As pointed out by Cole (1954), the birth rate, the death rate, and the age composition of the population, as well as its ability to grow, are of course consequences of the life history features of the individual organisms. Discussing population consequences of life history phenomena rather deductively, he declared the necessity of comparative studies of life histories, and

inception of diapause in NS at $20^{\circ} \mathrm{C}$.

At $20^{\circ} \mathrm{C}$ it was impossible or nonsense to investigate the density effect on the inception of diapause except in NS, because all or nearly all the larvae in other stocks entered dapause irrespective of their larval densities.

In NS, being reared in the highly crowded conditions (800 1000 eggs per $40 \mathrm{~g}$ of rice bran in a large petri dish), most of the larvae wandered out of food at a fully grown stage, and the state in the petri dish was similar to that of a dish in which temperature-dependent diapause larvae wandered and spun up tent-like webs all over the surface of the dish and food.

In this case, however, the characteristic feature was the state of food which was almost completely eaten and replaced by the excretions of the larvae. This state of food was rather similar to that of the exceptionally high density rearing in OS after presuming every existing pattern of life history may have survival value under certain environmental conditions, he concluded that the study of these adaptive values represents one of the most neglected aspects of biology.

When dealing with a classification of the ecological interspecific relationships between the closely related species of Japanese butterflies, the author (Tsurr, $1958 \mathrm{~b})$ reached a similar conclusion from the inductive standpoint.

The studies on the ecological life history should not be merely "accumulated descriptions of morphological, physiological, or sometimes ethological phenomena in connection with the life cycle, but be a new scientific system itself which must be formulated for the special purpose of resolving population problems.

Cole proposed life history features such as total fecundity, maximum longevity and statistical age schedules of repro- 
duction and death. Of course the way of classification of such life history features. itself may be a subject of the studies on the ecological life history. In order to investigate ecological life history more practically, such features should be approached from the inductive point of view. For example it is necessary for the studies of existent population of insects to investigate the pattern of features such as fecundity, speed of development, type and stage of diapause, method and stage of migration or habitat orientation, and degree or extent of fitness for environment including foods.

So, in this paper, the diapause problem was taken up from such a standpoint, and the results reported were on the flexibility in the diapause character of a species population.

The establishment of NS may perhaps be interpreted as a result of selection in the direction of freedom from the temperature-dependent onset of diapause at a constant temperature of $20^{\circ} \mathrm{C}$.

Although the effect of temporal adjustment in the development of a generation upon the temperature response of the succeeding generation does not seem to be of great importance in establishing NS, it seems from the data that there are some effects of the $20^{\circ} \mathrm{C}$ rearing of parental generation on the earlier emergence of the $F_{1}$ adults, as the parental moths are not selected in regard to the time of emergence. There are other data similar to this (unpublished data).

The establishment of DS may also be regarded as a result of selection in the reverse direction to NS.

There are two main possibilities as regards the cause of modification in the density response of $O S$. In the first place, there may have been progress of selection in the direction of freedom from the density-dependent onset of diapause, because for the purpose of mass culture each generation of OS has been reared in the condition of high larval density, and in order to repeat the experiments as quickly as possible only the moths emerg-: ing early were used for collecting eggs; so that the density-dependent diapause: individuals which alway emerged later (Tsul, 1959a) were excluded from the stock in every generation. The second possibility is the effect of the condition of previous generations upon the density: response of later generations though there is no positive evidence for this posibility.

There are many species in which natural selection has tended to favour the evolution of genetic strains which respond differently to environment. Geographical races differing in the diapause character have been described in Pyrausta nubilalis by many authors including BABCOCK (1927), Babcock \& VANCe (1929), Arbuthnot (1944), WrESSELl (1952), in Gilpinia polytoma (PrebBle, 1941), in Locusta migratoria (LE Berre, 1953; Yakhimovich, 1950), in Telea polyphemus (DAwson, 1931), in Chilo suppressalis (FuKaya, 1948), in Barathra brassicae, (MASAKI, 1956) and in Bryobia (Mathys, 1954). In Bombyx a graded series of phenotypes can be traced ranging from univoltine strains with obligatory diapause to multivoltine strains with facultative diapause or virtually free of diapause (NAGAtomo, 1953). There are other species in which new strains could be built up with continued selections. The cases such as in Locusta migratoria (LE BERRE, 1953), Ephestia elutella (W ALOFF, 1949), and Antheraea pernyi (TANAKA, 1951) are examples.

From the ecological point of view these examples show that the population of many insect species has a considerable flexibility in the character of their diapause as well as in that of their resistance or tolerance to the environmental conditions including insecticides and natural foods. The significance of the results reported in this paper is that the flexibility in the character of diapause has been shown not only in the response to density-independent factor but also in density dependency itself. It is likely that the mode of response to density may 
sometimes be modified independently of that of response to density-independent factor. Therefore $O S$ is rather similar to DS in the mode of response to temperature but the intensity of density response is quite different from each other, and OS is similar to $\mathrm{NS}$ in the mode of density response but there is a great difference in that of temperature response between them (Tables 2 and 3 ).

\section{SUMMARY}

There was a reduction in the number of density-dependent diapause individuals in the original stock of Plodia interpunctella HÜBNER reared at $30^{\circ} \mathrm{C}$. The percentage of density-dependent diapause decreased from $23.7 \%$ to $0.6 \%$ during three years from 1956 to 1959 (tested in the condition of 400 eggs per $30 \mathrm{~g}$ rice bran at $30^{\circ} \mathrm{C}$ ), whereas all or nearly all of the larvae entered diapause when they were reared at $20^{\circ} \mathrm{C}(\mathrm{OS})$.

On the other hand, by repeated breeding from the moths which emerged relatively early at a temperature of $20^{\circ} \mathrm{C}$, a new stock was evolved that pupated without any interruption even under this temperature condition. This stock was also not so sensitive to larval density, showing $0.4 \%$ diapause in the condition of $400 \mathrm{eggs}$ per $30 \mathrm{~g}$ rice bran at $30^{\circ} \mathrm{C}(\mathrm{NS})$.

By the same handling method as in NS and by selecting in the opposite direction, another new stock was evolved that produced little or no diapause-free individuals in every generation at $20^{\circ} \mathrm{C}$. This stock showed a marked sensibility as regards the effect of high larval density of 400 eggs per $30 \mathrm{~g}$ rice bran at $30^{\circ} \mathrm{C}$,resulting in $52.4 \%$ diapause (DS).

All the larvae of the three stocks entered diapause if they were reared at $30^{\circ} \mathrm{C}$ up to the middle instar stage, at which they were removed to $20^{\circ} \mathrm{C}$. No larvae of the three stocks entered diapause when they were reared in a condition of low larval density at $30^{\circ} \mathrm{C}$.

The significance of the results reported in this paper is that the flexibility in the character of diapause has been shown not only in the response to density independent factor but also in the mode of density response itself.

\section{ACKNOWLEDGEMENTS}

The author wishes to express his gratitude to Professor Syunro Utida not only for his criticism, but also for his interest and encouragement.

\section{REFERENCES}

Arbuthnot, K. D. (1944) Tech. Bull. U. S. Dept. Agr. No. 869, 20pp.

ВАвсоск, K. W. (1927a) Ecology 8: 45.

ВАВсоск, K. W. (1927b) Ecology 8: 177.

BABсоск, K. W. \& A. M. VANCE (1929) Tech. Bull. U. S. Dept. Agr. No. 135, 54pp.

Cole, L. C. (1954) Quart. Rev. Biol. 29: 103.

Dawson, R. W. (1931) J. Exp. Zool. 59: 87.

Fukaya, M. (1948) Nōgaku Kenkyū 37: 121.

LE BERRE, J. R. (1953) Biol. Bull. 87: 227.

MASAKI, S. (1956) Bull. Fac. Agr. Mie Univ. 13: 29.

Mathys, G. (1954) Mitt. schweiz. ent. Ges. 27: 137 Cited by Lees (1955).

Nagatomo, T. (1953) Bull. Fac. Agr. Kagoshima Univ. 2: 1 .

Prebble, M. L. (1941) Canad. J. Res. D 19: 350.

TANAKA, Y. (1951) J. Seric. Sci. Japan 20: 191.

TsujI, H. (1958a) Japan. J. Appl. Ent. Zool. 2: 17.

Tsuji, H. (1958b) The Insect Ecology 7: 94.

Tsusi, H. (1959a) Japan. J. Appl. Ent. Zool. 3: 34.

Tsuj, H. (1959b) Japan. J. Appl. Ent. Zool. 3: 250.

Waloff, N. (1949) Trans. Roy. Ent. Soc. 100: 147.

Wressell, H. B. (1952) Ann. Rept. Ent. Soc. Ontario 83: 43.

Yakhimovich, L. A. (1950) C. R. Acad. Sci. U. R. S. S. (N. S.) 73: No. 5, 1105. Cited by LEES (1955). 


\section{摘要 \\ ノシメコクガ Plodia interpunctella HüBNER の生態学的生活史の研究}

I ・休眠生起についての 3 ストックの比較

辻 英 明

京都大学農学部昆虫学研究室

ノシメコクガ Plodia interpunctella HÜBNER $30^{\circ} \mathrm{C}$ で累代飼育しているうちに, 幼虫の生息密度に対する感 受性が著しく弱くなり, 密度依存的な休眠率が 3 年間に $23.7 \%$ から $0.6 \%$ になった（いずれも $30 \mathrm{~g}$ のぬかに 400 個の卵を投入し $30^{\circ} \mathrm{C}$ で飼育)。しかし $20^{\circ} \mathrm{C}$ で飼 うと休眠した (OS)。

一方 $20^{\circ} \mathrm{C}$ で比較的早く羽化する成虫を繰り返し飼育 した絬果, $20^{\circ} \mathrm{C}$ の恒温では休眠しない 新しいストック が手にはいった。このストックもやはり密度に対する感 受性が弱く，OS と同じ実験方法で $0.4 \%$ しか休眠には いらなかった (NS)。

NS と同じ方法で反対の方向に選択飼育して, $20^{\circ} \mathrm{C}$ で累代飼育しても休眠するストックを手に入れた。この ストックは密度に対する感受性が強く, OS, NS と同じ
実験方法で $52.4 \%$ の密度依存的休眠率を示した(DS)。 ぞのストックも $30^{\circ} \mathrm{C}$ の温度と低い幼虫密度の条件下 で飼うと休眠にはいらない。一方発育の初期を $30^{\circ} \mathrm{C}$ で 飼って後期を $20^{\circ} \mathrm{C}$ に移すと, NS を含めて全部のスト ックが休眠する。

OS 注温度反応では DS と似ているが, 密度反応では 大きく異なっている。また OS 滵度反応では NS と 似ているが, 温度反応では大差がある。

ここで得られた結果で重要と思われるのは, 休眠の特 性についての種内変異が, 密度依存的でない温度の働き に対する反応に久られるばかりでなく, 密度の働きに刘 する反応にもはっきり認められ，しかもそれが温度反応 の変化と注るる程度独立的に生じていることである。
抄

\section{アブラムシに対するアルファルファの耐性とその発㕕}

\section{段㳻との関保}

Howe, W. L. and G. R. Pesho (1960) Influence of plant age on the survival of alfalfa varieties differing in resistance to the spotted alfalfa aphid. J. Econ. Ent. 53 (1): 142 144.

アルファルファの 4 品種にアブラム、シの一種 Therioaphis maculata (Buck roN) を接種し，その耐性と発 育段陼との関係を調べた。抵抗性品種 Lahontan およ び Moapa の枯死率は植物の発育段階の進行とともに 低下し, 感受性品種 Africanもこれらとほほ同様の傾 向を示した。しかし Caliverde ではどの発育段階の植 物も枯死率は非常に高かった。すなわち Caliverde の
耐性は極度に低いと考光られ，てれを除いては一般に発 育段陼の進んだ植物のほうが幼路植物よりるアブラムシ に加害された場合強健である。成熟した抵抗性品種はア ブラムシに対して選好性, 抗生作用の面で抵抗性が強い と同時に加害に対する耐性を持つているといえる。てれ に反して Caliverde のような感受性品種では選好性扔 よび抗生作用に関して抵抗性が弱い上に，植物自身の強 健性も低いため，大きい害を受けるのであろう。

本実験はかでをかぶせて行なったので, てれらの結果 は野外にみられる現象といくらか異なってはいるが, 品 種間の抵抗性の差異に関し、よく野外観察を説明してい る。

（農工大農 一瀬太良） 